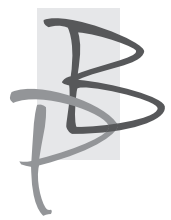

Marcin Bajko*

Uniwersytet w Białymstoku Wydział Filologiczny

https://orcid.org/0000-0001-9031-0966

\title{
Spotkanie z kulturą tatarską w Suwałkach. Sprawozdanie
}

Pierwszego dnia grudnia 2018 roku w Suwałkach odbyła się Międzynarodowa Konferencja Naukowa „Poszukiwanie wspólnych korzeni kulturowych Polaków i Tatarów”. Było to już czwarte suwalskie spotkanie popularyzujące wiedzę o kulturach naszych sąsiadów. W latach poprzednich sesje poświęcone były kulturze litewskiej, białoruskiej i ukraińskiej. Konferencję zorganizowały: Państwowa Wyższa Szkoła Zawodowa im. prof. Edwarda F. Szczepanika w Suwałkach oraz Katedra Badań Filologicznych „Wschód - Zachód” z Wydziału Filologicznego Uniwersytetu w Białymstoku. Organizacją sesji - jak co roku - kierowała dr Barbara Nowacka, natomiast część naukową koordynował prof. Jarosław Ławski.

Sesję otworzyły przemówienia: dr Marty Wiszniewskiej - Rektora PWSZ w Suwałkach, dr Agaty Wądołowskiej - Dziekana Wydziału Ochrony Zdrowia PWSZ oraz dr Małgorzaty Andryszczyk - Prodziekana Wydziału Ochrony Zdrowia PWSZ. W wypełnionej po brzegi sali zebrali się w mroźny grudniowy poranek nie tylko studenci PWSZ, lecz także suwalczanie zainteresowani

Marcin Bajko - doktor, adiunkt w Katedrze Badań Filologicznych „Wschód-Zachód” na Wydziale Filologicznym Uniwersytetu w Białymstoku. Autor m.in. książek: Heroiczna Apokalipsa. W kręgu idei i wyobraźni Tadeusza Micińskiego (Białystok 2012), ,, Sny niezwykte o Polsce i o Europie”. Diagnoza kultury w pismach Tadeusza Micińskiego u progu Pierwszej Wojny Światowej (Kraków 2015). Kierownik grantu NPRH „Naukowa edycja krytyczna Pism rozproszonych T. Micińskiego w czterech tomach” (2016-2019). 




Dr Marcin Bajko (Wydział Filologiczny UwB) Fot. PWSZ w Suwałkach

problematyką. Wszystkich powitała dr Nowacka, która o godz. 10.00 poprosiła o zabranie głosu trzech referentów, w tym specjalnego gościa z Krymu, Tatara Krymskiego. Wysłuchaliśmy następujących wystąpień:

Dzieje Tatarów Krymskich $\boldsymbol{w} X X$ wieku - dr Nariman Seitiahiaiev, Tawrijski Uniwersytet Narodowy im. Władimira Wiernadskiego (Kijów, Ukraina), (tłumaczenia z języka rosyjskiego Anna Samoilenko - studentka PWSZ w Suwałkach);

Wschód bliski i daleki. Tadeusz Miciński o islamie, Turkach i Tatarach - dr Marcin Bajko, Katedra Badań Filologicznych „Wschód - Zachód”, Uniwersytet w Białymstoku;

Tatar romantyczny: narodziny mitu - prof. Jaroslaw Lawski, Katedra Badań Filologicznych „Wschód - Zachód”, Uniwersytet w Białymstoku.

Szczególne słowa podziękowania winniśmy doktorowi Narimanowi Seitiahiaievowi, który specjalnie na tę okazję przybył z Kijowa, gdzie wykłada dzieje kultury, piśmiennictwa i historię Tatarów od czasu, gdy po aneksji Krymu musiał opuścić mury uczelni w Symferopolu. Doktor Seitiahaiev w niemal godzinnym przemówieniu, połączonym z prezentacją materiału fotograficznego, przybliżył dzieje Tatarów Krymskich, rozbijając przy okazji wiele mitów, stereotypowych wyobrażeń na temat Tatarów i muzułmanów. Między inny- 


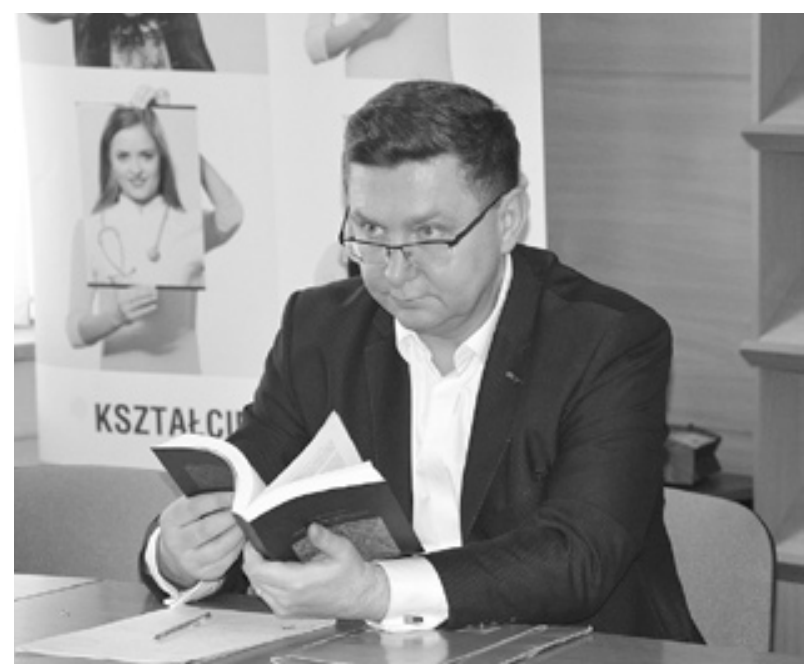

Prof. Jarosław Ławski (Wydział Filologiczny UwB)

Fot. PWSZ w Suwałkach

mi zarysował dzieje szkolnictwa, ruchów politycznych oraz podkreślił rolę zjazdów kobiet tatarskich w życiu tego narodu. Szczególnym, poruszającym momentem jego wystąpienia było nawiązanie do stalinowskich deportacji tej wspólnoty, których kontynuacją są represje na Krymie w Putinowskiej Rosji. Całość obrazu miała wydźwięk tragiczny - Tatarzy, którzy nie tak dawno cieszyli się z powrotów do swej krymskiej ojczyzny w niepodległej Ukrainie, po aneksji Krymu znów są uchodźcami i społecznością prześladowaną.

Dr Marcin Bajko przypomniał sylwetkę Tadeusza Micińskiego nie tylko jako wybitnego poety młodopolskiego, lecz również publicysty, polityka, reportera i w końcu oficera, który często i pozytywnie pisał o muzułmanach na Bałkanach oraz Tatarach polskich z okresu I wojny światowej w Rosji.

Z kolei prof. Jarosław Ławski opowiadał o skomplikowanym tworzeniu się w XVII-XIX wieku mitu tatarskiego, który wykreowały wspólnie: wyobrażenie Tatara jako bitnego, wiernego Rzeczypospolitej lub walczącego z nią wojaka, osadnictwo tatarskie, przedstawienia motywów tatarskich w malarstwie i ich niezwykle liczne metamorfozy literackie, moda na romantyczny orientalizm i (już w XX wieku) początki oryginalnej twórczości Tatarów polskich (litewskich). Badacz nawiązał do dzieł poetyckich Antoniego Malczewskiego i Tomasza Augusta Olizarowskiego, tworzących oryginalny wizerunek Tatara. 


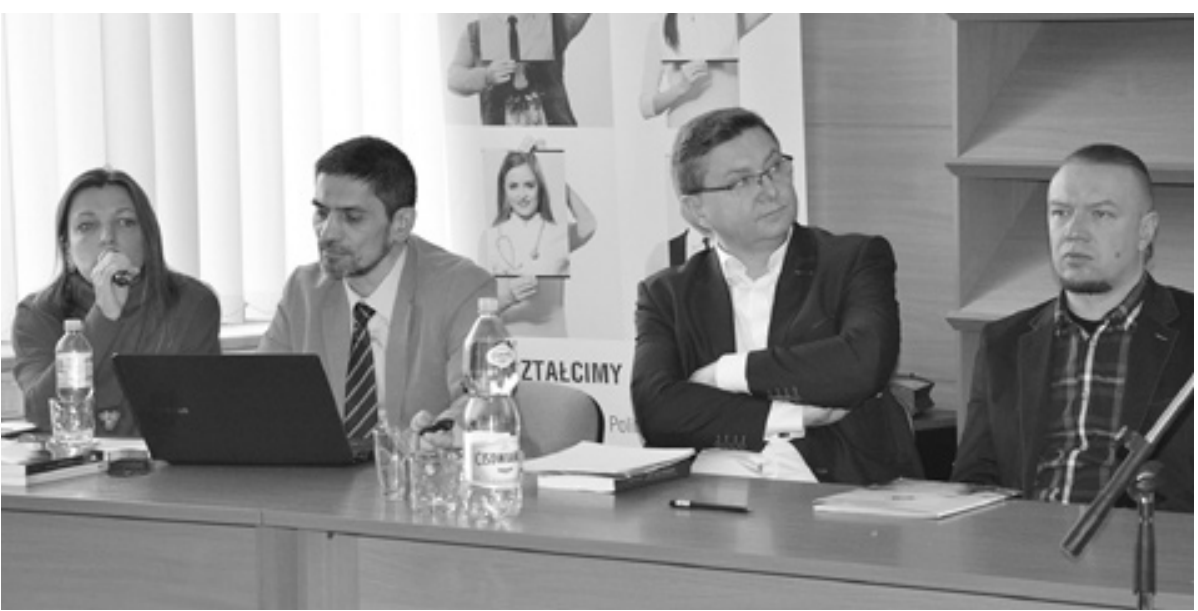

Obrady plenarne pierwszego dnia Konferencji

Fot. PWSZ w Suwałkach

Tradycyjnie już Konferencję zakończył akcent muzyczny - występ zespołu „Złota Jesień” Uniwersytetu Trzeciego Wieku w Suwałkach. Po występie można było osobiście zadawać pytania prelegentom. Wśród gości Konferencji znaleźli się tego dnia imam i przewodniczący Muzułmańskiej Gminy w Polsce.

Władze PWSZ w Suwałkach oraz Wydziału Filologicznego UwB zgodnie zadeklarowały wolę organizacji w 2019 roku kolejnej konferencji, tym razem poświęconej kulturze niemieckiej bądź łotewskiej. 